\title{
中國的語 言淟
}

\section{羅常 培}

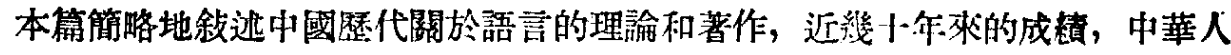
民共和國成立後語言學的新方向, 斯大株同志語言學萑作對中國語言學的影響。
\end{abstract}

中國古人對於語帚的看法一一中國有五千年

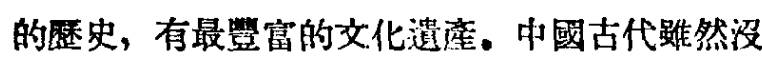
有語言學這倨名月，賽際上也作了不少語霍學方 面的工作。在古書中常常可以看到關於語言的理 論，雖然是片段的，可是非常精来。現在藇㮔做 例子來䛦。

触國時的大哲學家苻子(約公元前335-255) 說: “名無固宜，約之以命。約定俗成謂之 宜， 異於約者謂之不宜。”(䓄子正名篇) 三國 時候 的随康 (223-262) 詨: “夫言非自然一定之

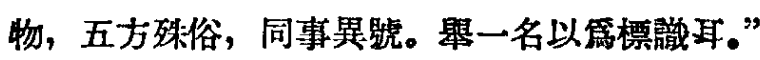
(秘中散集聲無哀樂論)〔1]用現在 的話 來說: 在起初定名的時候, 名葐跟事物的烈保是偶 然 的。換言之: 語言是人門在邧會中交際的工具, 字晋跟字義只有事實的關係，沒有必然的閣係。 這是語言學的重要原則，認識這一點，我們甫能 此較語言, 研究語言的親屬關係。

東漢的哲學家王充(生於公元27卒於98-101 之間）說: “䨐以明志。言恐滅遺，故著之文字. 文宇與語言同䖯。……經傳之文, 聖賢之語, 古 今言殊, 四方談異也。”（論衡自紀篇）他 很 正 確的說明語言文字的關係; 古書難懂的理由是古 今語言有變遷, 及有方富的美別。這是語言學的 基本原則, 認識語言是演變的, 我們戈能研究語 害的歷史, 語言的缯展。古書的注解寒, 常常有 古今詞壕不同, 語音不同的話。例如: 東漢末年 㣀去（127-200）的周䣓（春目外史）注說:

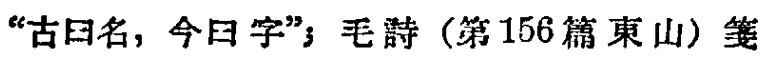
說: “古者聲栗烈周”。跟溴玄同時的劉熙在他的

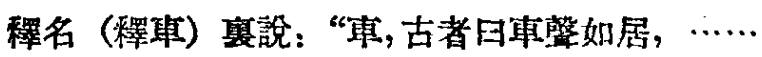

今日車臂近食。”由此可見中國古代的學者已 經 認識語言足紧的。

訓詰一一訓詰就是解橴古代的字義，主要是 注解古書。現存經典的注解，可以追湖到漠朝 (公元前 206-公元 220)。谨朝最有名的經 火師鄭玄所作的詩經、周禮、儀禮、澧記的注 解, 都足徂重要的著作。漢朝以來, 歴代學者都 有很好的成績。陸德明（約 554-64:2）的䌈典

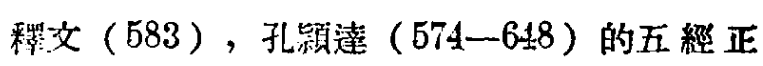
義，都是總結前人意見的著作。哲學家朱意 （1130-1200）也注解了好些古書, 如祛集傳、 論語集註、孟子集註、楚鿷集註。陸德明、孔穎 達以及其他唐朝（620-907）的學者偏重字竟 的解釋，朱喜以及其他宋朝 $(960-1279)$ 的學

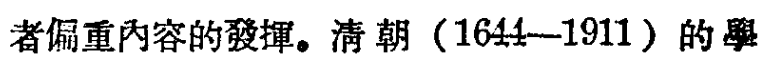
者在訓詁方面成就最大, 美不多每一種重要的經 典，都做了新的注解。除了注解古書以外，在字 義方面，䍝有許多獨立的研究。其中最特出的是 戴震（1723-1777）、段玉裁（1735-1815)、 王念孫（17414-1832）、王引之 (1766-1834， 王念孫的兒子）。戴聚的詩經補注、段玉裁的設 交解字注、王念孫的瀆書雜志、廣雅疏證、王引 之的經義述開、經傳䊅詞, 在古代字義研究上都

[1]以後也有類似的理掄，例如無能子（序題光警 三年，即公元 887 ）紀見第入: “且萬物之名，亦豈自

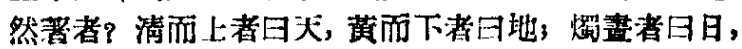

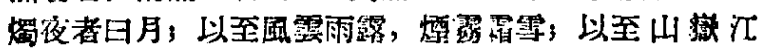

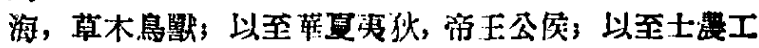

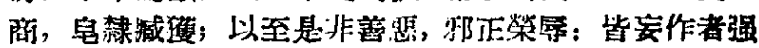
名之也。人久㖬之，不兄其强名之初，故沿之而不敢移

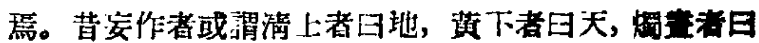
月, 虽变者日日, 今亦治之矣。”
4 月號
科學通報 
有卓越的貢獻。清朝以前，古書的注解主要的是 㯾文解義, 訓詀只是篇解釋古書用的。清朝學者

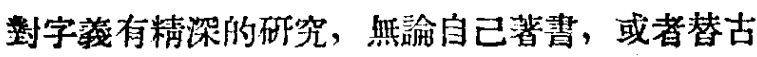
書作注, 都有成系統的獨立的見解, 訓站打成篇 一門學問。這一點不是偶然的，因篇他們對古音 學有修䓹, 所以對古字義有梁刻的認識。[2]

字典——中國字典可以按能例 分成 四種: （一）沿有注解的分類字策，是識字課本性翼， （二）有注解，按意義編排的字 些，（三）有注

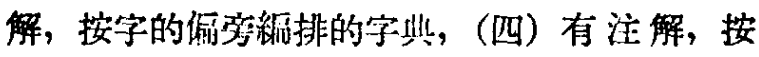
字晋縟排的副書。逥四種體例代表字典發展的四 倜階段。第（四）項留到下節討論，本節先討論 前三項。

（一）沒有注解的分類字繻可以追溯到公元 前八世紀的史等篇, 現存鼠古的是史游 (公元前 一世紀）的急就章。这早的都不存在了，只能從 古書的引證和新發現的漢代木简上找到一部分。

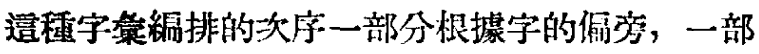

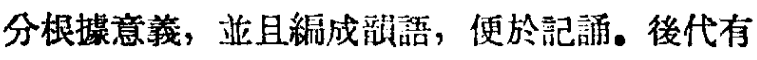
不少這類的識字課本, 如周興勋 $(471 ?-521)$ 的千字文, 和各地流行的“雜字”之類。

（二）按意義編排的字㠫，最古的是政雅， 相傳是周朝初年周公 (公元前十一世紀) 所作。 濖說法不罗得可信。根據稳健的估計，大概是公 元前三世紀緛定的。酎雅共分十九章。前三章佔 全書的三分之一，是字義的解釋，大部分把義同

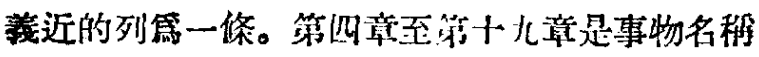
的分類，如“天、地、II、水、草、未、鳥、鄂” 等。後代模倣爾雅的畫很多, 最早的是魏（220265) 張撮的廣雅, 書名的意思是爾雅的援大 或 補編。

楊雄（公元前 53一公元 18 ）的方言是中 國 第一部㲹錄方豆的書, 也是按意義排列的。其中 大部分詞笨注明通行的澡域, 哪些是全國通行 的, 哪些限於某些地方。他的材料來源有古代的 典籍, 有直接的調查。二千年前就調查方言, 逜

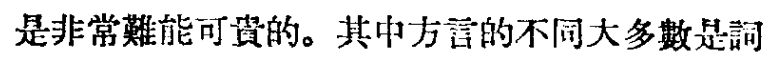
㖟的不同, 例如: “舟, 自 (函谷) 關而西謂之 船, 自閣而東或謂之舟, 或謂之航。”也有一些

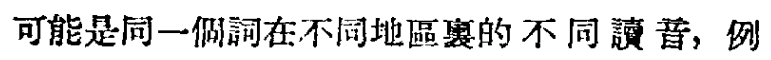
如: “自關而東曰逆, 自關面西或曰迎。”逆字迎 字古曋相近, 都是迎接的意思。後代模倣方蒠的
書地不少。

劉然（公元二世紀）的釋名是一種分類字 勧, 共云十七章, 包括“天、地、山、水”等。蓄 中用晋同勇近的字來解釋字義, 想用這種方法來 推究事物得名之由, 所以叫做“釋名”。例如: “冬、終也。”終是末了的意思, 冬足一氛的末了, 所以用“終”字來解釋“冬”字。䢙種解釋字苸的方

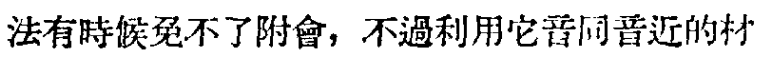
料, 對於推测當時的昔親, 倒也有一些密助。

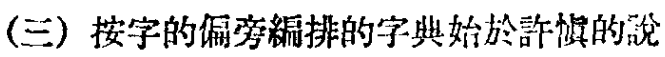
文解字(公元 100 ，簡移說交)，遭是有意識地䄽成 的字典。全書分成 540 部, 共收 9,353 字, 其中 大部分是形馨字。形馨字由兩部分組成。一部分 是形, 鄙意義有關, 多牛是說交解字的部首, 例 如: “江、河”都是水字旁, 都在水部。一部分是 監, 跟謮音有關, 例如: “江”字從“工”蹈, “河” 字從“叮”罄。說文解字部首次序大部分跟形能有 關係。唐宋以來涗文解字是研究中國交字的主要 参考書, 十七世紀以後研究的人更多, 講說文解 字的專書和論文合起來有幾百種。說文解字以後 按部首緛排的字监非常多, 其中特别著名的是䫏 野王（519-581）的玉篇（518）, 其 16,917字。 原書注解列舉古書中㹂例, 體例非常完善。可惜 現在只存在一部分殘织。現行的玉籍是陳彭年等 在 1013 年改鼣的, 分部大骽根㨜馀文解字, 共

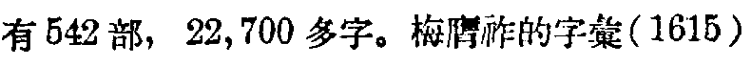
依譃說文解字, 䠰併部首, 共 214 部。清代官修 的康熙字典成害於 1716 年, 共收 47,021 字, 分

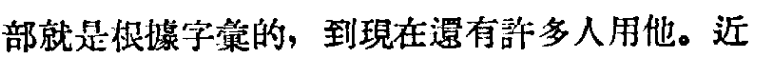
喽十年出的字舆, 通行最廣的是鿷源、鲜海, 單 字沼有康熙字典多, 分部闹康熙字典一栐, 除毠 字外, 特别着重典故和成語的解釋, 並且包括很 多新的名詞。

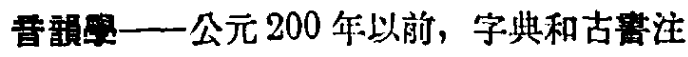
解的注兵, 都用晋同或者乓近的字來比擬，不容

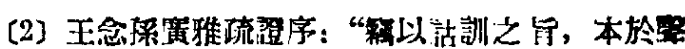

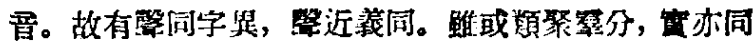

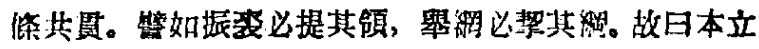
而道生，知犬下之至青而不可敦也。此之不筑，則有字

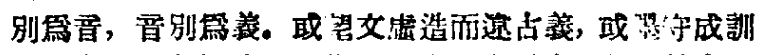

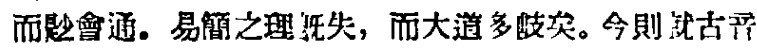

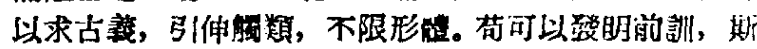
淩雜之識, 亦所不剧。” 
易馀得明白潐確。公元三世紀墢明了反切的方 法, 把每個字的音 (一僻字是一個㝜節) 分析成

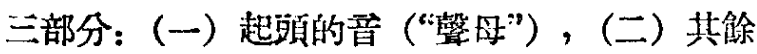
的音 (“轒母”)，(三) 全音節的番高(“聲調”)。 反切用兩個字将表示一假字的音, 上字表示被切 字的“馨母”, 就是跟紴切学“隻馨”; 反切下字表

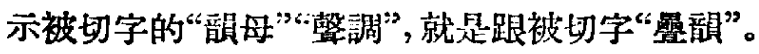
比方說“耐 най 奴 ну 代 дай 切, 酎奴兩字的馨 母都是 н, 酎代兩字的到但都是 ай，耐代兩字

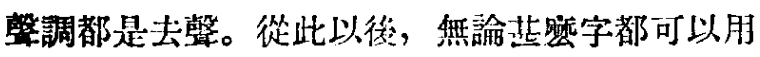
反切注晋。就漢字這種非拼音的文字而論, 用反 切注曋的辦法是比較簡毠㟆確的。現代的語言學 家認篇, 分析漢藏語系的語言, 每個音節分成這 樣三部分是最方便的。

有了反切, 少有按吾彩排的字典, 就是䫓書。 最早的是魏 $(220-265)$ 李登的馨類, 其次是绩吕 静的韵集(公元 300 年左右), 現在都不存在了。 最重要的䫓書是陸法言 (二陸訶)的切韻 (601)。 切韵的序上明白地說, 切嘳不僅是實用的書, 也 是審晋的書。[3]切暗流行全國, 有許多增訂本。 最晚的增訂本是 1008 年的廣 嘼。切副原本已經不存在，最近墢現許多唐人抄 寫本, 其中有一偑王仁昒的堆訂本 (706) 是完 整的。 ${ }^{[4]}$ 切堷系韻曾在中國語言學上地位非常重 要。研究現代漢語, 叮以拿切到的系統來說明各 方言的語音變㴗和方霄炎間的關係。研究切韵以 前的音韻系統，也得從切䫓往上推。

有了韵書, 才有韻臨。這是一種表格, 同一

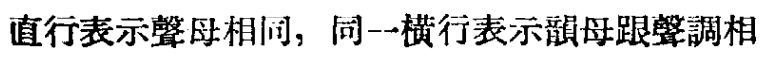

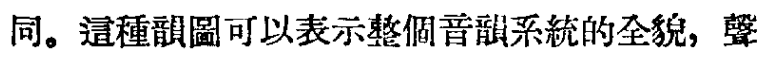
韵配合的關係。現在的語言學家認篇, 要描竄漢 藏系語言的曋系，塄種淁格是不能缺少的。堷圖 大概在九世紀就有，不過現存副圖最早是十二世 紀的。大歴史家鄭樵 (110t-1160) 的通志七音 略是根據切韵系䫓書的，同時代的切韻指掌圆却 根據當時語音加以調整。以後出現的堷圖不外選 兩部書所代表的考古和德音兩派。

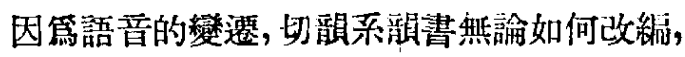
都不能表示當時的語音棌統, 非有新䤃書不可。 1324 年出了周德帮的中原望䫓， 1375 年出了宋

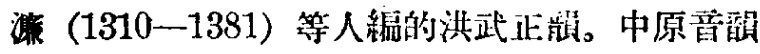

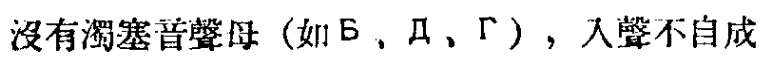

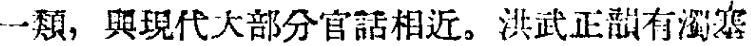
堛馨母，入蹈自成一類，與現代哭語相近，

阮元 (176t-1849) 等人緛輯的經籍算詁 （1799），把古書的 注解，分字收維，按㨽絧 排，是很有用的寥考書。近年出的融書，最主要 的有國語鲜带，除單字外，多收白話及現代常用 的詞。

古人踓然知道古今音異, 可是有系統的研究 古音是從吳棫（約1100-1155）開始的，他著了 一部港叫骠補。古晋的研究在清朝有 飛躍的進 步，我們舉六倜人來說。顧炎武（1613-1682)

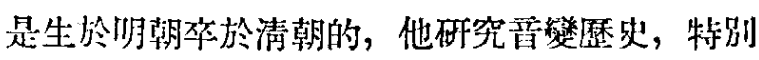
着重每一種音部現象最早出現的時期。段王裁 (1735-1815) 首先指出諧聲字同一馨行的字在

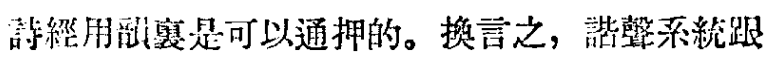

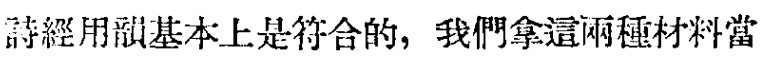
作內部一致的材料來研究沼有多少例外。根據造 两種材料，就可以把上古番的翮目分成好些部。 上古音的分部工作因此就越来越細密，到王念係 (1714-1832)、江有誥 (1851花) 幾乎已經到了 頂點, 可以補充修改之瓧已經不多。錢大听 (1728 -1801）是第一话研究古代馨母有成績的，首先

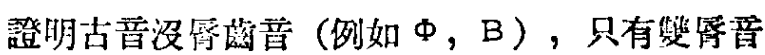

(例如 $\Pi ，$ B， M )。陳澧 (1810-1882) 著切

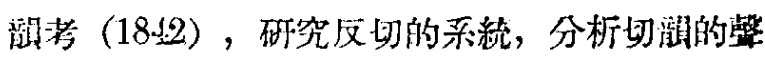
㽬，他的方法和結論，用今天的語蓄學的哏光來 批評，基本上都是站得住的。

外國語言的㸴究一一公元一世紀，佛敘傳入 中國，中國人接解到結丵跟淡語完全不同的筑 交，翻譯了大量的佛經，保存了無數印度已䌡失 傳的其籍。同時梦文的研究對中國音到學也起了 影響。焚交字母按照發番部位發篔方法排列，是 最利學的。反切已經分出字音的聲母跟椡母, 可 是馨好的系統排列法是店朝一倠和分守温（九世

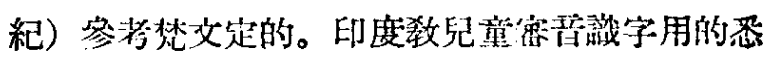

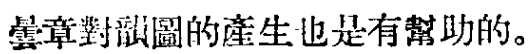

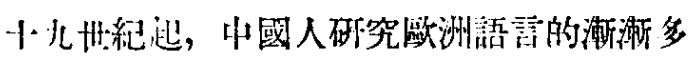
了。悲建忠 (1841-1900) 對拉丁文很有㸴究,

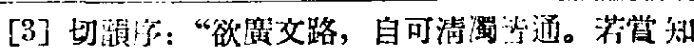

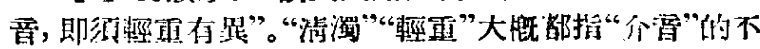

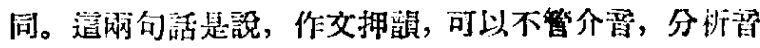
激就型分得子細。

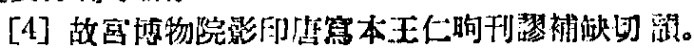


他察出了第一部漢語語法一一馬氏文通 (1898)。 在他以前也有討論虚字用法的畫, 可是有系統的 語法遭是第一部。

從上一穊我們可以看到，糜朝歷代的中國人， 有很多般䄈的語言學家。不過因篇交字不是拼音 的, 他們不能不偏重抽象的語音分類跟語音當中 的關係, 比較忽略語昔本身的音优。好些古代學 者的著作，要等待現代語言學家作語普學的解

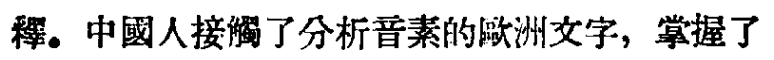
分析普素的工具, 語音學大有進步, 同時語言學 也大有進步。

近㹽十年来, 中國語言學家碑究的籍圍不限 於中國的語言。關於印䟷語, 也發 表了好些論 文. 亞洲各國的語言, 中國人向來很關心, 如越 南語中的漢語借字, 印度尼西亞語的語法, 都有 著作表。

近烧十年來的工作 近炼十年來的工作, 主要的是漢語方言的調查研究, 漢語語法的㸴 究, 漠語歴史的研究, 漢字改革研究, 漢藏系語 吉的調查研究。本急先討論前三項。

中國的語䨐可以分成三個人區域來說。東南 各省的力言最椱雜, 造一區域包括廣東、福建、 台潛、江西、浙江五省的全部, 湖南省的大部分, 廣西、安微、江蘇三省的一部分。行三區是 “官

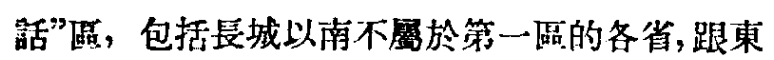
北的大部分。換句話流，長江以北及四川、雲值、 責州等省的漢民族, 铚的圶是“沱話”。第三區包 括內蒙、新疆、青海、西康、西藏以及河哃各省 的透地, 說的是不闰的助族語跟“涫“話”。造一區 土地表不多佔全國的一斗, 人口却不到企國的十 分之一。漢語的方污可以分成儿組，第一澡公組,

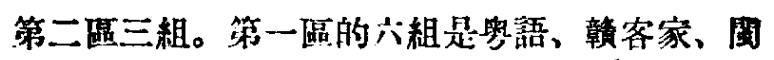
南、間北、舆語、湘語。第二區的三粗足北方“官 話”、西南“官話”、下江“官話”。北方“官話”包 括黄河流域和東北, 北京話盧於造一組。“官話” 的共阔特點是音系比較簡單。說各組“官萿”的 人, 他們之間可以随便談話, 各人用自己的方音,

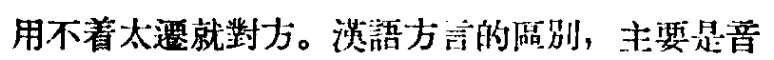
系不同，其次是詞素，語法的差異最少。

北京話可以說是全國的共同語, 音系語法都

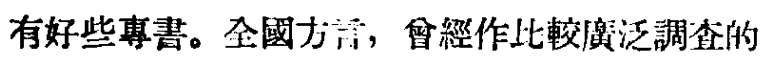
有江蘇南部、浙江、廣東、䔮唒、汇西、湖湳、
湖北、焉南、四川、安微南部、陈西中部等處， 已經寫成報告發表的很多。

漢語語法有系統的研究始於溤上文通, 不過

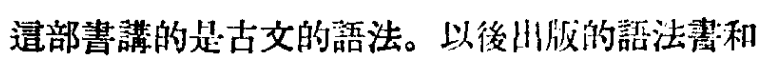
單篇論文很多, 有講古文的, 有渋口語的, 咑比 較古今語法的, 對漢語句法紹棈有比校精密的分 析。漢語的語法, 最主要的是字㡺和絬啃的展次。 向來大家都知逆字序在漢語中的活要性。還柯一

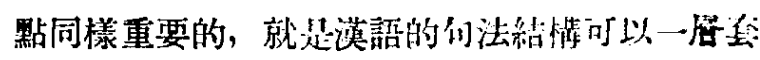
一屡, 任何一種結構當中都可以包含别的結構, 不必用好些連接成分。只要婄清展次, 條理就非 常清楚。例如:

他 II 不來。

他 II 很好。

(他 || 不來) I| 很好。

“他不来”是主謂結構當主語用，“很好”是 謂語。

我川看見 | 他。

我 \|看見川（他川來了）。

“他來了”是主謂結構當筫語用。

我們 11 反對 | 美帝國主義。

我們 11 反對 | (武裝 1 日本)。

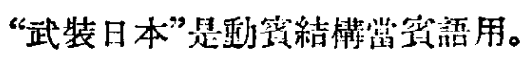

我們 || 反對 |(美莦國主義 || 武裝 | 日本)。

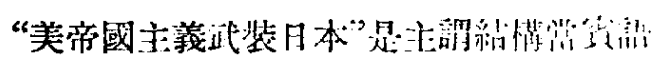
用。

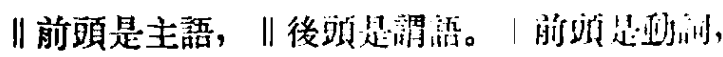

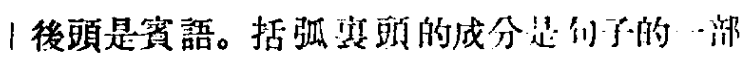
分, 可是本身文可以分析。

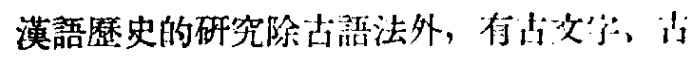

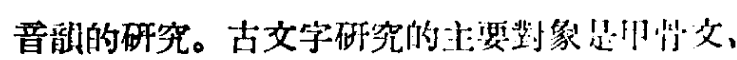

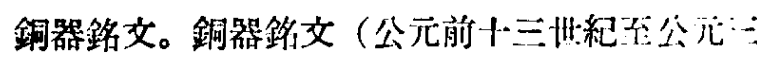

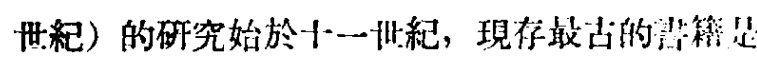

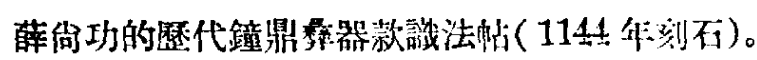
甲骨交 (公元前十三世紀至前十一州紀) 㓦婄

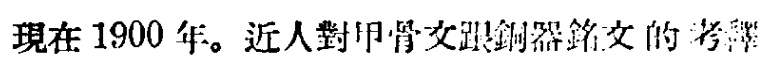

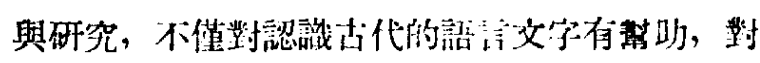

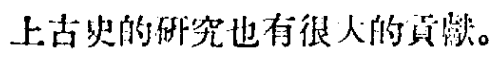

章俩䗲（1868-1936）和他的學尘黄织

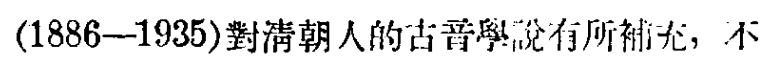

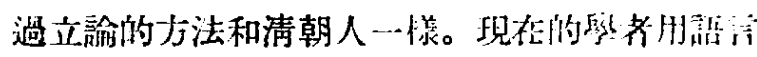

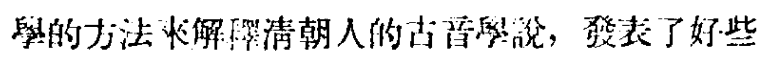




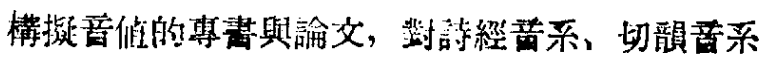

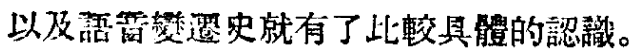

漠字改革 漠語有方言的差別, 漢字却是 全國統一的。谨字的意義到處一樣, 讀音却随方 言而異。各方言中漢字的瀆音踓不相同, 各方言 的謮音之間却有一定的殿係。漢字的優點是通行

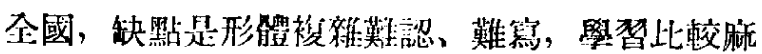
煩。朋末清初就有些人自到漢字的缺點, 十九世 紀起, 不断有人提議如们改革漢字, 以便晋及敎 有。就力法流, 主要的标簡化漢字與拼音兩派。 簡化漢字派的目的是提部學晳漢字的效率。拼昔 派又呵分䉆两支：一支用各種拼音符號分析聲母

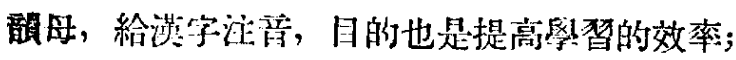
一支用拉丁字母分析曋素, 目的是拿它來造成拼

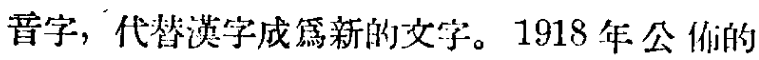

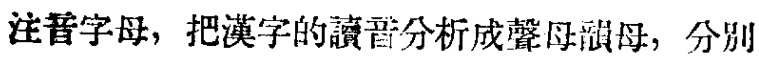
用字母（利用漢字的古解）表示。這话辦法在基

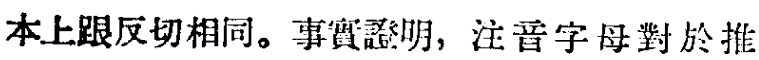
行識字運動, 功效顯著。1928 年公佛的國語 羅 馬字，1931 年訂定（後谏略有修改）的拉丁化 新文字, 都是分析普素的。在標音方法上, 兩 者都探用拉丁字母, 主要的不闹是: 國語䍜馬字 用拼法表示馨調, 拉丁化新交字在原则上不標 馨調。

中止人民政府成立以後, 特别閚心亚且努力 設法提高全國人民的文化水本。一方唯組織中國 女字改革研究委員會 (1952作2月5日)，研究 中國文字拼音化和漢字穊化的問題; 一方面入少 推行裁字運動, 普及敉育。1949 们開始實驗的 “速成識字法”, 利用注音字母, 約在一百五十小 時左右的数學時間队，可使一般文目和織字不多

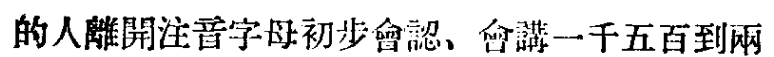
千個漢字。這種敉學方法的创造與推行, 只有在 解放以後书有可能。人民民主尃政制度的優越 性, 這襄又提供了一侗證據。

\section{少數民族語言研究中國是一假以漢族篇}

丰觰的多民族國家，除㴖治外，據不完企的調烃， 少数民族在六十種以上。企國少數武族的人口， 䄪計四千英人方:有, 很多分佈在邊境, 地區遼

閣, 所佔驺積約佔企國總面積的 $50 \%$ 以上。 全國少数工放的語言可以作如下的分類:
(一) 漢藏晤系
1. 洞台語（洞水語，公

蓓)

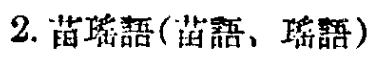

3. 藏䌐語(藏铻、語、 荆读語等)

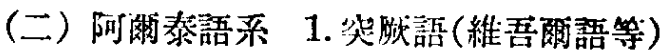

2. 蒙古語

3. 通古斯語（滿洲、錫 伯、梙倫、赫哲、鄂 倫漼等唔）

（三）印歐語系（俄睢斯語、塔吉克語）

（四）南島語系（台㩐高仙語）

（五）南亞語系（雲南絟甸交界的崩龍語、 西語)

其中漢藏語系人口最多, 阿爾永部系次之, 其他三系人口都很少。

在少數民族語言中，調查工作做得最多的是 谨藏浯系，有好些調查報告發表。其中洞台䇎的 工作做得较多，發表的著作不限於紀錄調查，隶 且有深入的研究。我們知道, 漢藏語系都是有字 調的; 古聲四帶音、不帶音决定字調的發屡, 侯 空音跟送莱成分也有它一定的作用, 古代的帶音 的塞音聲母常常變成不帶音的。從這些勢看

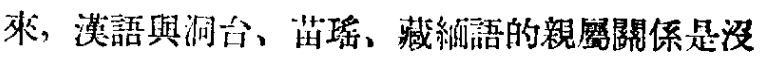
有問題的。關於洞台浯跟出瑤語的字調與㹂的

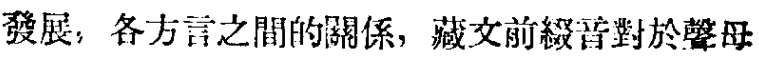
的影響, 藏緬語的浯法, 都算經有重要的論文搏 表。

中華人民基和國成立以來，正確地執行了共

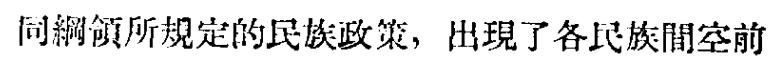
未有的大疄結。因此, 語言研究工作叮以配合政 策、結合䫏際地服利進行。语言學工作者也熱誠 地馨助沼有交字的少數施制定文字, 或改革其 舊有的不合用的文字。西康西旦域的新文已 經實驗推行, 成績供坟。還有許多少數民族語言 已經編出敎利望，在積極試敎中。

除了這些現代語以外, 還有些古浯言, 現在 已經沒有人說, 不邀㷟有紀錄存在。關於吐火羅 文 (古印歐語) 、契丹文、西夏文、文畺文, 都 有專書及論文發表。

斯大林同志對中國語言量的影㛭 1950年: 6 月 20 日, 斯大林间志在点理硍上發主了“諭馬

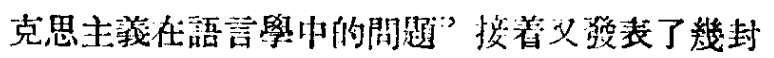




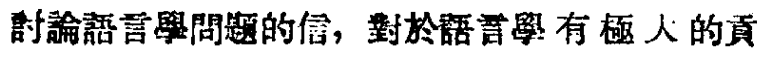

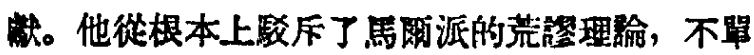
給蘇聯的語尊學開閣了，新路，同㭙也給中國語言 學指出了明確的方向。他的文章暲成中文以後， 立到引起全中國學術界的注意，並且展閉廣泛的 討論, 聯遙到文字改革、翻臎工作、語文敎學和 語言學家的任移等問題。1950 年12月9 日中國 科學院語言研究所召開了一個大規模的座談會, 來討論斯大林同志的語言學理論。他的理諭對中 國語言學的工作也發生了很大的影響:

（一）過去中國語言學界鼬重語言本身的問 題, 專題研究和方言調查有好些存在着朌離現䝿 的偏向。解放以後, 語言學工作者學晳了騳克思

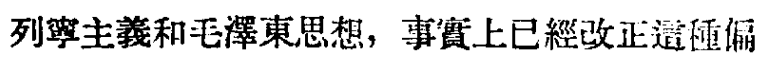
向。現在聽了斯大林闰志的文章，更從理諭上:有 了明確的認識。準備着在斯大林同志語言學淰的 基礎上, 結合中國語言研究的具能情况, 建立中
國語喜的系統的理諭。

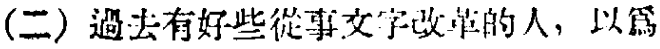
語言文字是有階級性的，因此起了一些想路，現

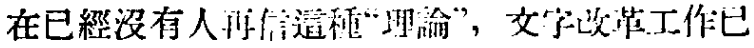
經走上了正確的迕路。

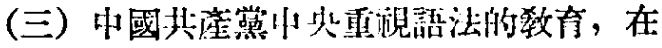

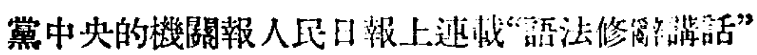
(1951 年6月 6 日至 12 月 15 日），䊼正文理

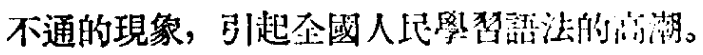

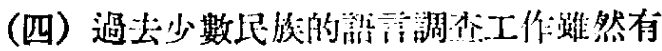
成精, 可是不够普掘, 不够深人。周查的䋨果對 少數民族的文化生活沼有多少幫助。三年以來在

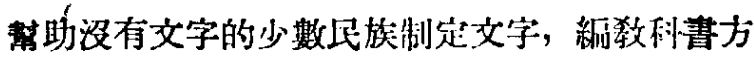
面，把語言調查跟語文敎育結合起隶，已經獲得 了若干成績。

在中國語霄學的未來發展中，斯大林的語言 學理論必然要發生更大的影響。

\section{〔上接35頁〕}

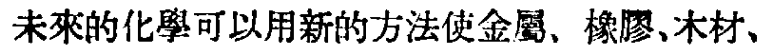
玻琌相互堅固地結合在一一起，這種新的方法按其

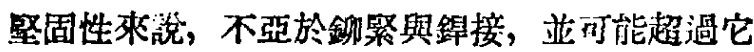
們。

學者與生產革新者的例造性的合作，給科學 與技術展開了十分黄涺的解迹。科學工作人員與 生産人員的創造性的合作，加速了我國技術操作 過程, 促進了蘇聯工業的發展。

斯大林改造自然計劃的順利完成，以米丘林 生物學篇基礎的先進的蘇聯農業技衎、以最優等 機器和有效的肥料加强農業, 這使田地和牧場的

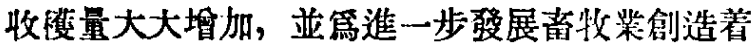
佟件。農作物增加了我國的物質財富。實現共産 主義的基本原则一一各取所需有了絕對可能。

蘇聯鄉村正朝着它發展文化的 道路苟步前 谁。目前許多地區巳全部電氣化與無線電化。許 多集觶脤垗由很好的公路與電訊同各城市取得聯 絡。在聯合集能農莊方面，設有自己的生产大本 焒: 農業機器站、機械修理僘、載重汽車與小活

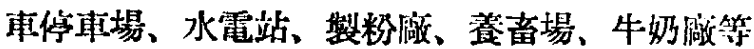
等。集解㖘荘菲員改楚了面貌，他們現在已絓都
成了拖拉機手、聯合收割機手、電或匠、辳學家、 動物飼食者。

科學與䒝衡的方向，今後將特别着眼於改善

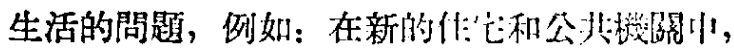

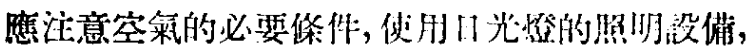

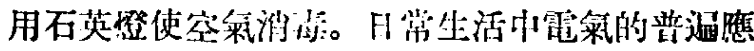
用，代替了然调和取湲的柴汕和蝶氣，用電氣能 洗內衣、地烲、衣服，能歇衣服。無線電傳員的 自動裝置網避及全國。

蘇聯學者與技術人員隨時慥地都感到泊已遠 癷於資本主義各國的學者與技㯎工作者，䄐是完 全有根據的。首先，我們正篇維蓝新生:的力量,

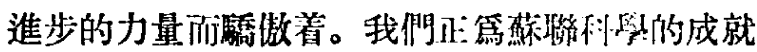

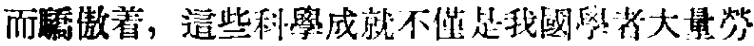

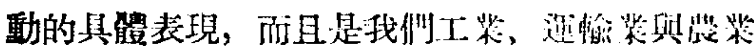
的蓬勃發展的，具體表現。双後我們坐媱我國科學!

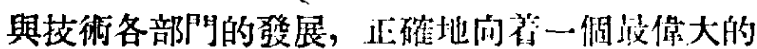

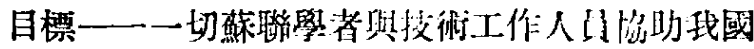

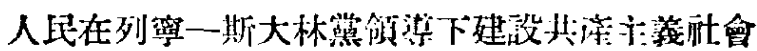

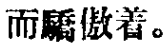

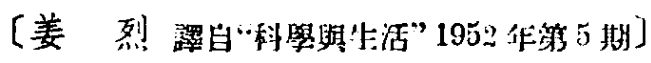

